\title{
THE IMPACT OF BEING WRONGLY ACCUSED OF ABUSE IN OCCUPATIONS OF TRUST
}

\author{
ROS BURNETT, CAROLYN HOYLE and NAOMI-ELLEN SPEECHLEY \\ Ros Burnett is Research Associate and Carolyn Hoyle is Director, Centre for Criminology, \\ University of Oxford; Naomi-Ellen Speechley is PhD candidate, School of Law, University of \\ Manchester
}

Abstract: In recent years, there has been rising concern that allegations of sexual abuse, particularly non-recent abuse, have not received an appropriate response. From this has emerged a new determination to correct past and prevent further injustices, with police operations focusing considerable resources on the identification and prosecution of child abusers. Police have adopted 'trawling' techniques to encourage reporting, and developments in the trial process related to the rules of evidence have eroded due process protections for suspects. This article considers this changed legal and social context, and the processes entailed in responding to allegations of abuse, before presenting original empirical data, gathered from the accounts of 30 men and women who were wrongly accused of abuse related to their employment in occupations of trust. It demonstrates the considerable and lasting harms done to those who face allegations of such heinous crimes.

Keywords: victims of sexual abuse; police investigations of non-recent abuse; rules of evidence; wrongful accusations

Recent years have seen rising concern that allegations of sexual abuse, particularly nonrecent abuse, have not received an appropriate response. Among politicians, ${ }^{1}$ criminal justice agencies $^{2}$ and charities ${ }^{3}$ in the UK, there is a collective sense of remorse that reports of abuse were often not properly investigated and that those who reported it were often not believed. Investigations into the abuse of children in care and residential schools in North Wales and northern England in the late 1990s were behind much of this unease. After some former staff were convicted of non-recent offences, there were widespread claims published in the media that abuse in such settings had been systemic, the work of 'paedophile rings' that sometimes 
'farmed out' victims to outsiders (Sawyer 2012). According to Webster (2005), between January 1998 and May 2001, 34 of the 43 police forces in England and Wales undertook investigations of non-recent institutional child abuse. While no organised paedophile rings in care homes were identified, ${ }^{4}$ fears of failing to bring to justice those suspected of such serious abuse changed the political and media landscape in ways that are still unfolding with the more recent allegations made against high-profile suspects. As we write, a new and shocking scandal of alleged widespread sexual abuse in football - being hailed as 'bigger-than-Savile' - is dominating our news media.

The reported prevalence of child abuse, rape and other sexual offences, both recent and historical, has risen steadily in recent years, reaching a new high in 2015, when rapes $(34,741)$ and other sexual offences $(68,873)$ were at the highest level recorded since the introduction of the National Crime Recording Standard in the year ending March 2003 (Office for National Statistics 2016). According to HM Inspectorate of Constabulary, the intense publicity afforded to inquiries such as 'Operation Yewtree', the investigation into alleged offences by the late disc jockey, Jimmy Savile, and other celebrities, have been responsible for part of the recorded increase (HM Inspectorate of Constabulary 2014).

From this has emerged a new determination to correct past, and prevent further, injustices of this kind. For example, the report of HM Inspectorate of Constabulary (2013), Mistakes Were Made, recommended that each agency with a duty to safeguard children and vulnerable adults should implement regular and systematic checks to ensure they comply with relevant policies and that a system of mandatory reporting should be considered to ensure that those who become aware of evidence that a child has been, or is being, abused is under a legal obligation to notify others of their concerns.

The now beleaguered Independent Inquiry into Child Sexual Abuse, aimed at investigating whether public bodies and other non-State institutions have taken seriously their duty of care to protect children from sexual abuse in England and Wales, invited victims and survivors of child sexual abuse to share their experience with the inquiry team, advising that the information provided will feed into the 'Truth Project'. However, it had been running for over a year before it was persuaded, in April 2016, to hear testimony from those who have been falsely accused, with then then chair, Hon. Dame Lowell Goddard, referring to 'the balance which must be struck between encouraging the reporting of child sexual abuse and protecting the rights of the accused'. Meanwhile the police have devoted ever more resources to investigating allegations of this kind.

While the police are obviously correct in taking seriously the investigation of allegations of abuse, there has been criticism of some police tactics in such cases and of changes to the law that weaken suspects' due process protections. In an abuse-conscious society, people may incorrectly remember or interpret events as abusive, or erroneously attribute abuse they suffered to the wrong person. They may exaggerate a non-criminal incident so that it is perceived as criminal, or, in some cases, may intentionally make a false allegation. The risk now is that mistaken or dishonest allegations of child abuse or rape are more likely to be taken as true, unless there is objective evidence to invalidate the claim. ${ }^{6}$ Although, as often, the evidence consists only of testimony from the alleged victim and is strongly rebutted by the alleged perpetrator, the moral imperative not to 'let down another victim' or to leave a possible sex offender free to cause further harm may be compelling. 
While this must, logically, reduce the chances of guilty persons avoiding prosecution ('false negatives'), it also risks increasing the likelihood of innocent people being presumed or found guilty ('false positives') (Burnett 2016). Sir Richard Henriques's (2016) independent inquiry into Operation Midland, and its investigation of non-recent sexual offence allegations against persons of public prominence, underlines the potential for policies that start from a position of 'believing the victim' to pervert the course of justice.

This article considers briefly this changed legal and social context, and the processes entailed in responding to allegations of abuse, before drawing on original empirical data to demonstrate the considerable harms done to those who are wrongly accused of such heinous crimes.

\section{Weakening Due Process Protections}

The weakening of due process protections for suspects in sexual cases goes back at least to the 1990s, when authorities were galvanised to act on claims that a culture of sexual abuse in residential schools for children 'in care' had gone undetected or been covered up. These allegations were mostly of historical (non-recent) abuse, and the principal evidence was statements from former residents of these approved schools, detention centres and community homes with education. Figures obtained from the Association of Chiefs of Police show that by May 2001 police forces in England and Wales had received allegations from about 5,750 former residents. According to Webster (2005), at least 10,000 former residents had made complaints by the end of 2004, with between 7,000 and 9,000 care workers having had accusations made against them: 'Most of these care workers have not been charged with any offence, but many ... had their lives blighted by false allegations. And in the last 15 years, as many as a hundred may have been wrongly convicted' (p.550 and footnote 605).

\section{The Emergence of a New Genre of Miscarriages of Justice}

Many of these complainants responded to police operations that employed techniques of 'trawling', a practice that has caused disquiet among many defence lawyers but also among the families of those affected by these cases. Concerns led to the publication of a House of Commons Select Committee on Home Affairs report, The Conduct of Investigations into Past Cases of Abuse in Children's Homes (House of Commons Home Affairs Committee 2002). This report looked critically at the methods police used in seeking corroboration for victims' claims - 'trawling' for witnesses. It stated that this, and the concomitant reliance on corroboration by numbers had led to 'a new genre of miscarriage of justice' (para. 2), adding: 'Set in the context of a growing compensation culture and a shift in the law of "similar fact" evidence, the risks of effecting a miscarriage of justice in these cases are said to be unusually high' (para. 2).

In appreciating the dangers of such an approach, it is instructive to look further back in time at the origins of similar fact evidence. It was intended as a safeguard to protect the innocent against the introduction of prejudicial testimony: 'similar fact' testimonial evidence was permitted only if there were 'striking similarities' between provable facts. This was extended by a Court of Appeal ruling in 1946 to include similar allegations. Two further judgments by the House of Lords in the early 1990s weakened the safeguards further. In 
1991, in $\underline{D P P}$ v. $\underline{P}$ ([1991] 2 A.C. 447), the Court rejected the requirement that allegations, to be admissible, should be 'strikingly similar'. In 1994, in $\underline{R}$ v. $\underline{H}$ ([1995] 2 A.C. 596), it held that, in ruling on the admissibility of a series of similar allegations, the judge should generally assume that the allegations in question were true (Webster 2002).

The timing of these judgments was significant, because police services were then just beginning to investigate claims of non-recent abuse in residential schools and care homes. Hence, 'the newly created weakness in the law was almost immediately seized on by police forces in order to successfully push through a number of prosecutions which could never have been brought prior to the decision in $\underline{D P P} v P^{\prime}$ ' (Webster 2002, p.5). Meanwhile, there was also widespread contact between the police and personal injury solicitors, gathering clients for large-scale civil actions against those allegedly responsible for abuse. These, it is argued, created opportunities for the exchange of descriptive detail, pollination of rumours and confabulation of memories (Webster 1998, 2005; Rose 2016). Some solicitors specialising in compensation claims advertised for self-identified victims using the prisoners' newspaper, Inside Time (Rose 2016). ${ }^{7}$ The risks here were self-evident; many of those responding to such advertisements had been convicted of crimes of dishonesty. They were also likely to come into contact behind bars with others who had been in care and approved schools, creating a further danger of collusion. In prison, it was also possible that some disadvantaged or vulnerable people who were not motivated by malice or greed were erroneously persuaded that they had been victims of physical and sexual abuse (Gunn 2013).

Developments to support victims of non-recent and recent sexual offences have continued apace, given impetus by advocates for victims of rape, and particularly since the eruption of the Jimmy Savile scandal and before that the emerging scandal of child sexual exploitation in English towns and cities (Child Exploitation and Online Protection Centre 2011; Berelowitz et al. 2012). The trade-off from these developments has been further erosion of due process and encroachment of human rights for those accused. Some of the developments have a bearing on all suspects who maintain innocence, but there are additional deprivations for those accused of sexual offences. The following outline of more recent policies, practices and statutes, that are prejudicial to the accused in sexual abuse allegations, is divided into those relevant to the trial process, and those that impact on the lives of people who are accused but never charged or who are charged but then acquitted.

\section{Developments Relevant to the Trial Process}

Rules of evidence: bad character, propensity and cross-admissibility

The use of 'similar fact evidence', or corroboration by volume, was significant in explaining the series of miscarriages of justice identified in the aftermath of the Waterhouse Tribunal (Waterhouse 2000; see below). With the implementation of the Criminal Justice Act (CJA) 2003, 'similar fact evidence' was largely overtaken by 'bad character evidence', although common law 'similar fact' principles are operative in the context of propensity and crossadmissibility of allegations (Edge and Mills 2016, p.129). 'Bad character evidence' is broadly defined and wide in scope (CJA 2003, ss. 98-113). It includes previous convictions, and evidence of specific acts of misconduct and reprehensible behaviour. But it also includes the 
following more speculative indicators of bad character: 'evidence of reputation for misconduct'; 'an offence for which the defendant has never been prosecuted'; and 'an offence for which the defendant was acquitted'.

In establishing the defendant's propensity for relevant bad behaviour, in addition to, or in place of, previous convictions, 'evidence that has not resulted in a conviction will commonly be relied upon by the prosecution where a defendant faces indictment containing several counts and it is argued that the evidence in relation to one count is admissible as evidence of bad character in relation to other counts (i.e. it is "cross-admissible")' (Edge and Mills 2016, pp.124-5, italics added; CJA 2003, s. 103(2)). Further, 'the judge is required to assume that the evidence is truthful unless no jury could reasonably believe it' (Edge and Mills, pp.125, 145; CJA 2003, s. 109). While the admissibility of these (arguably, more tenuous) forms of evidence may facilitate the achievement of more 'rightful' convictions, in a category of offending that is hard to prove or disprove, admission of such evidence risks some wrongful convictions based on false rumour and lingering suspicion. Where several counts involving different complainants are treated as cross-admissible, there is the risk of collusion and unconscious influence, or innocent contamination from one count to another (Forster 2011).

Judicial directions and warnings

Another legislative development that may have placed innocent defendants further in jeopardy of a guilty verdict was the removal of the need for judges to warn juries about the danger of convicting on uncorroborated testimony from the putative victim of an alleged sexual offence. Section 32 the Criminal Justice and Public Order Act 1994, abrogated the requirement to give a corroboration direction in respect of a complainant of a sexual offence. It was left as a matter for the judge's discretion what, if any, warning, he or she considers appropriate (Judicial College 2016, s. 10-2(3)).

From a prosecution perspective, the corroboration warning implied to juries that there is something less trustworthy about the evidence of a complainant of a sexual offence. Though the warning was applicable also to male complainants, Leahy $(2014$, p.43) notes that it 'was closely related to prejudicial fears about the purportedly mendacious nature of female sexual offence complainants'. Arguing against the retention of the discretionary warning, she is critical of the 'symbolic message which the law in this area has the potential to send [and] the impact which societal attitudes about rape or 'rape myths' may have on juror deliberations in sexual offence cases ...' adding that 'Amongst the more pernicious of these myths is that many allegations of sexual assault and rape are untrue'.

Yet corresponding arguments could apply from a defence perspective. Societal attitudes have moved on. Old stereotypes about unreliable complainants have been vigorously challenged while new ones have arisen - for example, that men attracted to working with children may likely be paedophiles. In a cultural climate that is now highly receptive to allegations of sexual abuse, the most dangerous myth, or fallacy, may be the insistence that untrue allegations are vanishingly rare. Many complainants of sexual abuse are men, responding to invitations to complain about historical abuse, with reassurances of anonymity. A warning about the danger of relying on the testimony of a single 'invited' 
complainant in the absence of any forensic or other evidence is not unreasonable, given the costs to defendants if found guilty.

Special measures for complainants in trials for sexual crimes

Special Measures can be granted by the court to 'vulnerable and intimidated witnesses' (Ministry of Justice 2015, p.15) (and complainants of sexual offences are automatically assumed to be vulnerable and therefore eligible, unless they opt out). These include: screens to shield the witness from the defendant; live links to enable the witness to give evidence during the trial from outside the court through a televised link to the courtroom; videorecorded interviews with the witness before the trial; use of an intermediary to assist the witness to give evidence at court (and at the investigation stage); and evidence given in private, after members of the public and press have left the court (except one named press representative).

Sparing the complainant in a sexual offence trial from face-to-face cross-examination by the defence is a humane practice, but may be in tension with Article 6(3) of the Human Rights Act, the right to examine witnesses against an accused. Hence, Special Measures might jeopardise 'equality of arms' necessary for a fair trial. They also indicate to the jury that the complainant is frightened or traumatised by the sight of the defendant. The scene is therefore set for the jury to make assumptions about the veracity of the complainant's evidence as compared with that of the defendant. Likewise, it would be unsurprising if use of the label (V) for 'victim', rather than (C) for 'complainant', in the Example Directions provided throughout the Crown Court Compendium (Judicial College 2016) did not sometimes affect the mind-set of judges in their summing up and directions to juries.

\section{Developments Relevant to Pre-trial and Post-acquittal Human Rights}

The Victims' Code and policing and Crown Prosecution Service practice requirements

The introduction of a Code of Practice for Victims, established by the Domestic Violence, Crime and Victims Act 2004, was a significant step forward in setting down the obligations of the State towards victims of crime. Following certain refinements and additional commitments (Ministry of Justice 2015) to improve victims' experiences of the criminal justice process, the Victims' Code provides something of a framework for policy and practice in the police and Crown Prosecution Service (CPS). Investigations following allegations of sexual offences are carried out from a position of believing the 'victim', with most official documentation choosing not to refer to 'complainants'. For example, guidance for police senior investigating officers under 'Operation Hydrant', established in June 2014 to coordinate police operations investigating non-recent child abuse within institutional settings and by 'persons of public prominence', underscores the importance of belief from the perspective of victims' therapeutic needs:

Adult victims who have been abused as children will often have experienced not being believed, being dismissed and silenced and feeling unable to share their experiences over many years. It is, therefore, essential that officers and staff now deal with their disclosures sensitively so that they can begin a 
process of recovery and have trust and confidence in any subsequent investigation. (College of Policing briefing $)^{8}$

Similarly, changes in the approach to complainants were reflected in the new Guidelines on Prosecuting Cases of Child Sexual Abuse, introduced in 2013. These steered prosecutors away from questioning the credibility of the complainant by challenging the 'myths' surrounding the reporting of sexual crimes (Crown Prosecution Service 2013, para. 41). The Guidelines also specified that "prosecutors should guard against looking for "corroboration" of the victim's account or using the lack of "corroboration" as a reason not to proceed with a case' (para. 55).

A report in 2014 by HM Inspectorate of Constabulary, Crime Recording: Making the Victim Count, recommended: 'The presumption that the victim should always be believed should be institutionalised' while 'The practice of some forces of investigating first and recording later should be abandoned immediately' (HM Inspectorate of Constabulary 2014, para. 7.16). Following on from this, the CPS and Metropolitan Police Service (2015) Action Plan on Rape asserts that prosecutors 'must focus their case on the behaviour of the accused, not the complainant' (Crown Prosecution Service and Metropolitan Police Service 2015, p.2). We might have expected the recent collapse of Operation Midland and apologies from the Commissioner of the Metropolitan Police, Sir Bernard Hogan-Howe, as well as subsequent wider debates about the police approach to allegations of sexual offences and abuse, to have resulted in both police and prosecution services being more circumspect in their approach to allegations of sexual assault. This does not appear to be so. The chief executive of the College of Policing, on 18 March 2016, wrote to all chief constables, police and crime commissioners and heads of public protection units to reinforce that the existing standards and guidance on the recording and investigation of sexual crime will not be changing (Marshall 2016). Similarly, the National Crime Recording Standard 'directs a victim focused approach to crime recording. The intention is that victims are believed' (Home Office 2016, p.3). On the face of it, this seems to be commendable. However, it creates assumptions that must be prejudicial to the accused.

'Pre-crime' sentencing: a further challenge to due process

The line between civil and criminal justice measures has been crossed with the introduction of preventive interventions and sanctions that operate outside of due process of law and that are, in effect if not intention, punitive (Thomas 2008). These include 'pre-crime' orders imposed on people who have been reported as showing a possible sexual interest in children, and which place restrictions on that person's liberty, listing them as suspected sex offenders.

Amendments to Part 2 of the Sexual Offences Act 2003, introduced by the Antisocial Behaviour, Crime and Policing Act 2014 have replaced and renamed previous orders, giving greater powers to the police in managing the risk of sexual harm. One of the replacement orders is a sexual risk order (SRO), a civil order that can be sought by the police against a person who has not been convicted, and can include a foreign travel ban. A condition of the order is that they have 'done an act of a sexual nature', including, for example, 'being alone with a child' or 'contacting a child on social media', but whether those and other acts are 'of 
a sexual nature' is decided according to a lower standard of proof than would be required by the criminal court.

Similarly, in the lead up to court hearings, or during periods of police bail, accused people may be restricted by the conditions of police bail from having contact with others, including their own children or grandchildren. ${ }^{9}$ While these measures are introduced with the best of intentions, and no doubt in some cases the suspicions are well grounded and the protections they afford will reduce risks, for those who are innocent they go against the principles of natural justice by making it appear to many outside of the criminal process that they are indistinguishable from convicted offenders. For example, suspected sex offender lists are accessible by the public and can influence those with power over housing or employment opportunities.

\section{Barriers to employment}

The effects of being wrongly accused extend to those who are not prosecuted, with civil safeguarding measures required by national or local government being punitive in effect. The accused are typically suspended from their jobs while investigations proceed, and subject to employment disciplinary hearings, and are likely to be discouraged from returning to the same employment after acquittal, given continued suspicion and cautiousness.

Applying for jobs that involve contact with children or vulnerable adults necessitates an enhanced DBS (Disclosure and Barring Service) check, and jobs that involve caring for them or sole supervision require also a 'list check'. Someone without any convictions but who has at any time been investigated in response to allegations of child abuse, rape and other sexual offences is likely to be affected because other data are held on police records that can be checked. The Police National Computer holds data on arrests, and the Police National Database records 'soft' local intelligence: for example, details of allegations or police investigations that did not lead to arrest or charge (Beard and Lipscombe 2015). Being at some time 'in the frame' can have lasting implications, which apply to voluntary work as well as to paid employment.

Creating a new class of victims?

The above changes have taken place in a climate of fear about sex crime in general - and paedophilia in particular - and a determination to believe those who make allegations. This was immediately apparent in the aftermath of the series of cases arising from allegations against staff in care homes in England and Wales in the final decades of the 20th Century. February 2000 saw the publication of Lost in Care, the report of the judicial inquiry led by Sir Ronald Waterhouse (2000) into abuse in North Wales, and on a BBC Newsnight programme that discussed the findings, Sir William Utting, former HM Chief Inspector of Social Work, commented: 'It may be that innocent people are being convicted, but we ought to be more worried about the guilty who might get away'. This baleful remark implied that the abuse of children, no matter how long ago, was such a serious matter that it merited a reversal of the legal principle of the presumption of innocence to increase the prospects of securing convictions. 
Today this determination to believe the complainant is stronger than ever. The recent Henriques (2016) report was highly critical of police policies describing complainants as victims. However, a statement on the website of the College of Policing, following publication of that report, pointed out that police use of the term 'victim' rather than 'complainant' was in accordance with the statutory requirements of the Victims' Code of Practice. It further reiterated that the policy had encouraged more victims to come forward who previously had not reported for fear that they would not be believed. While such policies reassure victims that they will be treated sympathetically, unfortunately they also pave the way for vexatious and erroneous claims to be believed, creating a new class of victim: the wrongly accused.

\section{Researching the Wrongly Accused}

The former MP, Claire Curtis-Thomas, spoke out about the lasting impact of an 'epidemic of false allegations' on those who were never charged, those acquitted and whose convictions were overturned. She recalled:

\footnotetext{
... the terrors people went through, facing imminent arrest, the horrible experience of that knock on the door and police searching the house and seizing property, then often kept in police cells so that they could not talk to other members of staff. Even if your case has been through the Appeal Court, your record has been tarnished and is never likely to be untarnished. Their reputations have been blighted and even though we see them and their families emerge from the court looking happy, we know that the blight has not been removed, because beyond that court there are many organizations and authorities who will hold on to that reputation of guilt, making it impossible for an individual to return to a life. That sort of injustice, which is not covered by legal redress must remain a huge concern to all of us that there can be these organizations who still treat you as guilty and will affect their lives forever. (Curtis-Thomas 2012)
}

There can be little doubt that accused persons will suffer to some degree when allegations of serious offences are made that cannot be readily refuted. The effects are likely to vary with the extent to which investigations and the criminal process develops, and the nature of the alleged offence. However, very little research has been done specifically on the impact of false allegations of abuse against those whose professional lives put them in close contact with potentially vulnerable people. Curtis-Thomas's testimony was based on anecdotal evidence from her constituents who had been falsely accused. We sought to conduct a rigorous empirical study to see if these experiences were common to others in similar situations.

We aimed to understand and share insight into the human costs of false allegations of abuse. While victims of abuse are increasingly given a platform to talk about what happened to them, people who are wrongly accused are not encouraged to speak out, either because they are not believed or because it is thought that they would undermine the credibility of victims of abuse and diminish their confidence to report offences. Thus, the purpose here is to start a conversation about the impact of being wrongly accused of abuse.

We conducted this research from a position of full and unequivocal support for the progress that has been made in recognising the problem of sexual and physical abuse of vulnerable people at the hands of those who should care for them. We applaud efforts to support victims of abuse. Furthermore, we understand that some claims to being falsely 
accused are also false. Some people will tell lies to deny the crimes they have committed to avoid both the shame and stigma associated with child sexual abuse, and the punishments imposed following conviction for such serious offences. We also fully acknowledge that once convicted, innocence is difficult to establish without irrefutable evidence to show that an accusation was false. In other words, in this area it is hard to establish who is guilty and who is innocent with absolute certainty. We have therefore taken a stringent approach to selecting participants for this study.

We analysed accounts from 30 in-depth interviews or written accounts provided by victims of false accusations and their families. Most of these were current or past members of a voluntary organisation that supports people wrongly accused of abuse in occupational contexts, ${ }^{10}$ though a few were contacted through a snowballing technique. In addition, we held focus groups at a conference for victims of false allegations. We interviewed people only if they had:

- not been charged with the alleged abuse (14 cases);

- were charged but acquitted (15 cases); or

- were convicted but had their conviction overturned on appeal (only if their convictions were overturned because of evidence of their innocence, and not merely on procedural grounds) (1 case).

Thus, all our participants have the status of 'legal innocence' based on the presumption of innocence until found guilty, or - for one person whose conviction was quashed - restoration to that presumption of innocence. Most of our participants were male, though six were women; most worked as teachers or in other educational roles; most allegations were of sexual abuse of children and the majority were non-recent ('historical') cases, though almost a quarter were recent. We acknowledge that it cannot be guaranteed that each of our participants are factually innocent, given the inherent difficulty of any legal disposition that relies on competing testimony. There is simply no clear empirical means that can settle the matter. However, all of them were legally 'innocent'.

\section{The Enduring Impact of False Allegations}

Our interviews explored the structural, cultural and psychological harms suffered by those who are falsely accused and the data show that they experience enduring trauma. After establishing some basic facts about the nature of the allegations against them and the ensuing criminal process, topics in the individual and group interviews, as well as the written accounts, focused on the wide-ranging effects of false allegations. Information was sought about the harms done to their employment prospects, to their finances, to their physical and mental health, to the effects felt by family members, to their own self-concept and reputation, beliefs and outlooks, as well as their wider relationships with friends and their community. Table 1 provides an overview of the numbers affected in these respects, and the following provides discussion of our qualitative data and examples of some participants' experiences. ${ }^{11}$ 


\section{Effects on employment and finances}

I am unable to foresee a way back into teaching any time soon both as a result of my anxiety and the hurdles that this allegation has and will present when applying for roles in schools. (Rhys) ${ }^{12}$

Most of our participants who were working at the time of the allegation lost their jobs or faced impassable barriers against working with children or vulnerable adults again.

Mechanisms to check the reliability of potential employees who wish to work with vulnerable populations - previously CRB (Criminal Records Bureau), now DBS, checks - can exclude those who have fallen under a cloud of suspicion even if they are not found guilty of any criminal offence.

Risk averse environments militate against those falsely accused and the upshot is damaged reputations and ruined careers. Innocent men and women are left without a career, while institutions lose skilled and caring employees. Several of our participants struggled to obtain references from their former employers. Arjun's former employer wrote a negative reference about him, despite a tribunal settlement ruling that they could not do so. Nicole describes how, even though she was not suspended or sacked, she was put in a position that prevented her from working in her chosen vocation:

The charity I founded felt obliged to obtain a safeguarding report, and that report was influenced by the fact allegations had been made which had never been tested in court but, because of the simple fact that allegations existed, the report could not rule out all possibility of risk. Charities have to act in a 'no risk' environment so I was asked to step down, with no opportunity of being able to clear my name.

There are considerable financial burdens accruing from this, but loss of earnings is not the sole consequence; the wrongly accused may also face steep legal fees, the loss of a home, and financial pressure on their partner.

All but two of the participants bore significant financial burdens despite awards of legal aid and damages. Several reported estimated losses of around $£ 50,000$ in legal fees, and much larger amounts for the loss of earnings while unable to work. In addition, many had significantly reduced pensions, given that they needed to take early retirement, and some whose residences were connected to their place of employment (for example, vicarages or accommodation attached to a boarding school) lost their homes, too.

For many, the loss of a vocation they had trained for and worked at for years caused multiple other harms. Being accused in an occupation of care or trust carries the additional consequence of the accused having to let down those they assisted in these vocations - both co-workers and children or vulnerable adults. Many of the participants expressed bitter feelings of loss concerning their inability to continue their work with children or vulnerable adults, with four participants specifically upset by being unable to help young people at risk of exclusion, children with learning difficulties and those in care. Rhys felt that he could not return to work, although he was not formally barred: 
Even had I been mentally fit enough to teach I would have been unable to. I have tried to return to a school setting through voluntary work but have found it incredibly stressful. I am unable to foresee a way back into teaching any time soon both as a result of my anxiety and the hurdles that this allegation has and will present when applying for roles in schools.

Measures taken to prevent the accused from discussing the allegations with colleagues make it incredibly difficult for them to mount a defence and prevent them from drawing on support from co-workers, who are often also friends. Marcus explained that:

\footnotetext{
Many did not understand my increasingly self-isolating behaviour because a lot of friends were colleagues, and so they couldn't be told what was going on ... part of me began burning bridges intentionally since it was all just a waiting game ... I could be facing trial for the allegations and I didn't want people to know, ... I knew that mud sticks.
}

For our participants, having to abandon care work, teaching, friendships and other working relationships spanning decades, resulted in social withdrawal, panic, fear, anxiety, and an inability to trust others, with the inevitable costs on mental health.

\section{Effects on reputation}

Such events change people profoundly and ... irreparably. (Marcus)

Those who have been wrongfully accused can feel that even when the system has recognised its error, others remain convinced of their guilt (Quirk 2007). This, perhaps inevitably, leaves them feeling stigmatised and afraid of what others think, and how they might therefore react to them (Westervelt and Cook 2010). The wrongfully convicted can feel that they have experienced permanent changes in their personalities, which cause them and their families significant distress (Jamieson and Grounds 2005, p.50). Many of those interviewed for the Westervelt and Cook (2010) study of death row exonerees had lost their 'old' self-identity on entering prison and were not able to rebuild it on release ( $\mathrm{pp}, 268-70)$.

As studies from various jurisdictions make clear, the stigma attached to being accused of abuse cannot be underestimated. It was a prevalent theme in each account. Stigma arose in two forms. First, from the actions and comments from others, who actively judged and excluded them, causing them to feel shame and hurt. David reflected that: 'the biggest shock is how differently you're treated by those around you', and Catherine explained: 'people whisper and talk behind your back [that] there's no smoke without fire. I feel I have to fight back and put this right but this also feels very lonely ... I feel criminalised'. However, stigma was also generated within the accused themselves; the combination of abhorrence at what they had been accused of, and their inability to fully clear their name, caused extreme pain and embarrassment. For Rick, the allegations had 'completely ruined my reputation ... most of my work has now dried up, even though I was immediately acquitted. References to the trial are still on Google ... consequently, my name has been tarnished, forever'. David, a former police officer, suffered extensive reputational damage arising from the negative publicity, and felt an acute pain at being unable to give 'his side of the story'.

Some of our participants struggled to reconcile the need to 'fight the allegations' with the desire to shut down and hide from the shame of an unwarranted label. Several accounts 
described the wrongly accused as a 'fighter', presenting a tough, no-nonsense person who would resist all suggestions of wrongdoing. The battleground analogies extended to support networks, with many describing others who were 'on our team', 'closed ranks', or 'came out fighting for me':

I really did find out who my true friends were. Some people I thought were close friends became distant, worried about the effect it would have on their lives and careers if I was found guilty ... they just couldn't take the chance of taking a hit to their reputation. Other people I thought of only as acquaintances came out swinging for me so hard I could have cried. (Owen)

Alongside this, however, our participants revealed fear and emotional vulnerability, and a sense of being worn down by the accusations and the concern that those close to them may be persuaded of their veracity. The stigma of the label 'paedophile' was a recurring theme in our participants' accounts, influencing their lives for a long time after they had been declared legally innocent. In such cases, mud really does stick.

Emotional trauma

I went through this horrible process of wanting to kill myself in order to escape the trauma that happened to me. (Joseph)

The majority of our participants reported high anxiety levels, severe depression, ill health and associated symptoms of trauma. Eight reported suicidal thoughts and twice as many revealed depression, although many more described thought processes and behaviour that are suggestive of depression. Many of those accused of sexual offences against children experience high levels of shame (Levenson, D'Amora and Hern 2007) and a recent report on non-natural deaths, following prison and police custody, demonstrates that arrest and police detention is particularly traumatic for individuals suspected of, or charged with, sex offences (Phillips, Gelsthorpe and Padfield 2016).

While studies in the UK and US have demonstrated the extreme psychological effects of wrongful imprisonment on men who had no prior psychiatric histories (Grounds 2005; Wildeman, Costelloe and Schehr 2011), in the present study, where 29 of the 30 participants were not even convicted and none were imprisoned, the same psychological effects were reported:

I have never visited the GP so many times in my life. I went into a state of shock for some weeks after my arrest ... . I suffered from depression, suicidal thoughts, self-harming, fear, immense anger against the police and my accuser and anger at the lack of support from anyone in authority. I went to counselling organized by the GP, but felt awkward and ashamed. I suffer stress-related physical pain and shaking. I was very close to suicide on at least three occasions. I still have nightmares and anger and even though it is all over and I was found unanimously not guilty. I still feel people are looking at me and judging me. My accuser is still in the area. I fear it could happen again. (Jack)

Wildeman, Costelloe and Schehr's (2011) research suggests that while many exonerees suffer from severe anxiety and depression in the years immediately following their release from prison, the psychological impact of being wrongfully convicted tends to diminish as they adjust to release. However, for those falsely accused but not prosecuted or convicted, there is 
no formal exoneration and many fear that some in their community will remain convinced of their guilt. This makes it difficult for them to put the matter behind them and move on with their lives. While our participants suffered acutely in the short term, many experienced longer-term symptoms, with 19 of the 30 reporting permanent behavioural and personality changes. As Owen put it:

The ordeal has caused irreparable damage. It has led to a permanent change in my character ... I'm a much more serious, cynical person now and I'm not as trusting of others. I'm wary of people and their intentions.

Andy, who was never subject to a police charge, had similarly experienced:

panic attacks, severe anxiety for which I required counselling, and severe depression. I was diagnosed as having PTSD. In fact, for virtually a two-year period I hardly ever left my home - not even to go shopping. Even now I rarely venture out alone. It is not an exaggeration to say I feel terrorized by these events and the conduct of one particular complainant ... It never goes away.

Ten participants' accounts explicitly mention post-traumatic stress disorder (PTSD) and serious shock directly resulting from the allegations. However, clinical symptoms were evident in a further seven accounts, with mention of being 'constantly under enormous threat', 'in a daze', 'a state of shock', and a 'hyper vigilant state', finding it 'incredibly hard to concentrate', 'bombarded with noise and lights', 'a very, very frightening period'. Susannah, the widow of a falsely accused man, recalled:

From the word 'go', he went into a kind of cocoon ... you would think that [someone with his knowledge and experience of criminal justice] would leap into action and start gathering evidence left right and centre ... not ever. I did all that ... he removed himself from the process, and zoned out during court proceedings .... The whole thing was distasteful in the extreme to him ... we never discussed his mental health, there was no point talking about it. We both knew he wouldn't survive 10 years in jail.

Damage to relationships

The greatest strain was on my relationship with my wife because we handled the difficulties in such
different ways. She was entirely supportive of me and did not doubt my innocence. But ... she coped
by wanting to talk about the matter all the time (while I wanted to say little about it) .... She was
angry, occasionally with me, but mainly with those who had made the allegations. I was puzzled and
hurt by the allegations, rather than angry. We found each other very difficult. (Stefan)

Research suggests that one of the greatest effects of wrongful conviction is damage to significant relationships (Grounds 2005, p.34). Experiences of estrangement (even from those who have fully supported them) and resulting feelings of guilt are not uncommon. In some cases, this can result in the breakdown of marital relationships as family members experience the wrongly accused as withdrawn, irritable, and emotionally disengaged (Grounds 2005, pp.31-2). Our participants shared similar experiences.

Every single participant account included distress at how they were perceived by others. Twenty-one admitted a loss of confidence - with resulting social withdrawal, terminated employment, fractured relationships, and lost friendships. George disclosed feeling fearful of what people would say in certain social situations. Others expressed an inability to relax, experiencing constant doubt and mistrust. James added that he felt 
vulnerable, nervous that gossip would circulate in the new area to which he had moved so that he might claim back his privacy. Though the case against her had not proceeded to trial, Ella described concern 'even now, that my family may still believe the things that were said about me'.

The effects of false allegations were felt by their partners and children too, with anxiety and depression experienced by many family members, in addition to consequential financial burdens. Kim, Jack's wife, explains:

I also suffered from shock which turned to depression. I lost two stone in weight in about six weeks as I could not bring myself to eat. I also needed counselling. I cried more than I have ever cried in my life, mainly with anger but also with feeling so helpless, being dumped in a system which I felt was just not working.

Restricted access to children and grandchildren is one of the deepest cuts of such allegations. Rob recounted the pain of lying to his grandchildren, who had previously often slept over at weekends, about why they could no longer do so. Even where there are no formally-imposed restrictions (which is rare), informal checks can occur, resulting from suspicion alone. Seven participants described their partner or other family members 'watching' them around their own children or grandchildren:

Perhaps the most upsetting feature has been the impact all this has had through me on my grandchildren. Whilst I enjoy a good relationship with them I feel very self-conscious in their presence and constantly want to be protected from any possible suggestion, and from whatever source, that my relationship with them might be questioned. I hardly ever interact with them alone and tend not to want to do even ordinary things with them in case this is viewed as 'grooming'. (Andy)

The stigma of a false allegation is felt by the whole family and can lead to family breakdown, or permanently damage the relationship. Six of our participants spoke of false allegations creating tension between them and their partners in the short and longer term, as George explains:

Initially our relationship didn't change, I believe she knew I was innocent throughout, but over time I became more unstable and less confident. ... I felt I was holding her back. We drifted apart, and she moved out.

Those whose relationships were irretrievably harmed met challenges when attempting to form new relationships. They cannot know 'who knows what' and so are faced with the choice either to inform others that allegations have, in the past, been made against them - and risk poisoning their own reputations and future friendships - or remain silent and suffer guilt and angst that the relationship could be ruined if the allegations are revealed. Clearly, being wrongly accused can poison future relationships as well as established ones.

Fear, alienation and mistrust

Most of our participants received no professional psychological support; either it was unavailable or they could not tolerate baring their soul to a counsellor for fear of being judged or disbelieved. The lack of support, formal and informal, apology or recognition of 
the pain caused to the accused was a constant theme. It resulted in deep mistrust of others, particularly those in authority and the media, and a sense of alienation.

Their trauma was, in some cases, aggravated by a fear of further allegations. Again, this very real concern separates this group of wrongly accused from many others who face false allegations. Being wrongly accused of murder or robbery is a deeply unpleasant experience but not so likely to be repeated once the status of the wrongly accused has returned to 'legally innocent'. Conversely, our participants, working with vulnerable and often troubled youths and adults, who may well have been abused in other contexts or by other people, were exposed to risk of further allegations that would be equally difficult to challenge. They had, in other words, rational concerns. These concerns about past and potential future allegations left a few feeling 'obsessive' about their cases. They pored over legal documents, attempting to investigate further the source of the allegations. This obsession is unsurprising but, in some cases, strained relationships with others.

The literature from both sides of the Atlantic suggests that many of those wrongly accused of these reviled offences identify themselves as victims of a range of 'perpetrators'. These may include: their accusers themselves; therapists who 'recover memories' and suggest that their client's problems were caused by repressed child abuse (Davis 2005); the police; and personal injury lawyers who put out calls for claimants while promoting their services in pursuing compensation (Webster 2005; Rose 2016). Ultimately, some will blame the State:

\footnotetext{
Whether the result of wilful, illegal conduct by state officials, implicit public pressure on and tunnel vision by police, an imbalance of resources in favor of the state, or sheer carelessness by investigators and prosecutors, wrongful convictions cause harm and produce victims. Exonerees' victimization continues after exoneration when the state fails to assist their reintegration efforts and recognize its responsibility in their wrongful convictions. [They can be understood as] victims of state-produced harms. (Westervelt and Cook 2010, p.261)
}

An overwhelming sense of anger and betrayal emerged from most of our accounts. More often this was not directed at their accusers, but at employers who were thought to have encouraged the allegations, at the police for what our participants saw as treating them as guilty from the outset, and at a 'victim-centred' criminal justice system with its provisions for complainants on one hand, and what they felt was a failure to recognise rights or due process of the accused on the other. Thirteen of our participants mentioned that their accusers were treated as victims before any truth in the abuse was found. This added to the sense of disillusionment at the failure of the justice system to protect their interests, and what they perceived to be a police investigation characterised by 'tunnel vision':

With a discourse calling the [complainants] victims, it has to be assumed that the police believed that those alleged against were correspondingly abusers and they continued to behave in this prejudicial manner to the bitter end. (James)

Most (24) of our participants expressed the view that victims' rights had trumped the rights of the accused. Marcus thought that the system 'is now in the grips of "perception" over fact'. Claude was pleased that vulnerable people were now afforded protection, but felt that: 'in the rush to protect vulnerable groups from the perceived threat of abuse, the pendulum has swung 
too far in the opposite direction'. Almost all our participants had lost faith in the criminal justice system, with some suggesting reforms to the laws on anonymity:

\begin{abstract}
It is of course right, in the light of the Jimmy Savile scandal and the degree of abuse which was covered up historically, to encourage and support genuine victims to come forward and report abuse. But I feel strongly that the pendulum has now swung so far the other way, that people are being hounded out of jobs or public roles merely on the basis of an allegation which might never actually be tested by any court or other judicial forum. This is a serious natural justice issue ... Complainants have anonymity, alleged perpetrators should have anonymity until conviction. (Nicole)
\end{abstract}

\title{
Conclusion
}

It is widely accepted that to be described as a sex offender or child abuser will be damaging. However, it may not be appreciated the extent to which a false allegation is likely to affect every aspect of a person's life, psychological, material and physical, even when the accused person is not charged or is acquitted. Most of our participants were able to refute the accusations made against them at a relatively early stage of the legal process. Despite this, their lives were ruined. It need hardly be stated that for factually innocent defendants who are wrongly convicted and imprisoned, but who cannot legally demonstrate this, the consequences will be still greater.

It is also of deep concern that the experiences described by the participants in this study are far from rare. A survey by the Association of Teachers and Lecturers (2015) of 685 of its members found that $22 \%$ of school and college staff had been the subject of a false allegation of abuse by a pupil The survey also found that the prevalence of false allegations and the publicity given to them is driving experienced staff out of teaching, and, presumably, deterring others from seeking to enter it. This is a damaging cost which society can ill afford.

In concluding, it is worth repeating the Metropolitan Police Service (2015) statement on Operation Midland: 'our starting point with allegations of child sexual abuse is to believe the victim until we identify reasonable cause to believe otherwise'. No doubt the intentions behind that statement were honourable: a desire to right an historic wrong, and to give victims who had been previously ignored, a voice. But this study suggests that in the process, a whole new and growing class of victims is being created, whose suffering is intense - the more so for having been largely ignored.

\section{Notes}

${ }^{1}$ See, for example, the Home Secretary's Statement on Historic Allegations of Child Abuse in North Wales, 6 November 2012. Available at: https://www.gov.uk/government/speeches/historic-allegations-of-child-abuse-innorth-wales-home-secretarys-statement-to-the-house-of-commons (accessed 6 February 2017).

${ }^{2}$ The Crown Prosecution Service (CPS) revised its policy; see also Starmer 2013.

${ }^{3}$ See, for example, NSPCC current advice. Available at: https://www.nspcc.org.uk/preventing-abuse/signssymptoms-effects/non-recent-abuse/ (accessed 6 February 2017).

\footnotetext{
${ }^{4}$ The recent inquiry by Lady Justice Macur (2016) found no reason to question the findings of the Waterhouse Tribunal with regard to organised paedophile rings in care homes (Waterhouse 2000). However, organised exploitation of vulnerable people in care and care-leavers has been found in several UK cities, notably Rotherham (Jay 2014).
} 
${ }^{5}$ Statement from the chair of the enquiry, April 2016. Available at: https://www.iicsa.org.uk/news/statementchair-inquiry-april-2016 (accessed 6 February 2017).

${ }^{6}$ Figures used by CPS (Levitt 2013) to indicate the low prevalence of false allegation of sexual offences refer to those where evidence refuting the allegation had come to light.

${ }^{7}$ This practice has continued; there are typically several such adverts in each issue.

${ }^{8}$ Summary of College of Policing National Guidance on Belief in Victims' Allegations. Available at: http://www.college.police.uk/News/Collegenews/Documents/Letter\%20on\%20investigating\%20and\%20recording\%20crime, belief\%20in\%20victims\%20A nnex\%20A.pdf (accessed 6 February 2017).

${ }^{9}$ See: (i) College of Policing 2015; (ii) Crown Prosecution Service website: $\underline{\text { Bail. Available at: }}$ http://www.cps.gov.uk/legal/a to c/bail/\#a03 (accessed 6 February 2017).

${ }^{10}$ FACT: $h$ ttp://www.factuk.org/ (accessed 6 February 2017). Fact's secretary wrote to all members notifying them of the study and attaching a Participant Information Sheet detailing the aims, methods and criteria for inclusion in the study, with contact information for the research team. No incentive to participate was offered other than the ability to contribute their story to research on an issue that had affected them personally. Not only did we set strict participation criteria, but we also required each participant to sign a consent form stating that they are factually innocent of any alleged offences of sexual or physical abuse, have never committed any such offences, have never pleaded guilty or accepted a caution for any such offence, and have never been convicted of any such offence, or have successfully appealed against any convictions and been exonerated.

${ }^{11}$ A detailed account of the findings is available in the full report of the study (see Hoyle, Speechley and Burnett 2016).

${ }^{12}$ All participants are identified by pseudonyms, and any potentially identifying information has been removed from quotations.

\section{References}

Association of Teachers and Lecturers (2015) 'False allegations are blighting careers and putting added stress on education staff', ATL press release, 26 March. Available at: https://www.atl.org.uk/latest/press-release/false-allegations-are-blighting-careers-andputting-added-stress-education (accessed 6 February 2017).

Beard, J. and Lipscombe, S. (2015) The Retention and Disclosure of Criminal Records (House of Commons Briefing Paper, Number CBP6441, 12 August 2015), London: House of Commons.

Berelowitz, S., Firmin, C., Edwards, G. and Gulyurtlu, S. (2012) I Thought I Was the Only One. The Only One in the World': The Office of the Children's Commissioner's Inquiry into Child Sexual Exploitation in Gangs and Groups, London: Office of the Children's Commissioner.

Burnett, R. (Ed.) (2016) Wrongful Allegations of Sexual and Child Abuse, Oxford: Oxford University Press.

Child Exploitation and Online Protection Centre (2011) Out of Mind, Out of Sight: Breaking Down the Barriers to Understanding Child Sexual Exploitation, London: Child Exploitation and Online Protection Centre. 
College of Policing (2015) Further Investigation. Available at:

https://www.app.college.police.uk/app-content/major-investigation-and-public-

protection/child-abuse/further-investigation/ (accessed 6 February 2017).

Crown Prosecution Service (2013) Guidelines on Prosecuting Cases of Child Sexual Abuse. Available at: http://www.cps.gov.uk/legal/a_to_c/child_sexual_abuse/ (accessed 6 February 2017).

Crown Prosecution Service and Metropolitan Police Service (2015) Joint CPS and Police Action Plan on Rape. Available at:

https://www.cps.gov.uk/publications/equality/vaw/rape_action_plan_april_2015.pdf (accessed 6 February 2017).

Curtis-Thomas, C. (2012) Speech to the Richard Webster Memorial Lecture, University of Wrexham, 13 October (unpublished).

Davis, J.E. (2005) 'Victim narratives and victim selves: false memory syndrome and the power of accounts', Social Problems, $\underline{52}$ (4), 529-48.

Edge, R. and Mills, A. (Eds.) (2016) Evidence, 18th edn, Oxford: Oxford University Press.

Forster, S. (2011) 'Cross-admissibility of bad character evidence', Criminal Law \& Justice Weekly, 175, 274.

Grounds, A. (2005) 'Understanding the effects of wrongful imprisonment', $\underline{\text { Crime and }}$ Justice, $\underline{32}, 1-58$.

Gunn, B. (2013) 'The compensation carrot and false allegations of abuse', FACTion, $\underline{4}$ (1), $10-12$.

Henriques, R. (2016) An Independent Review of The Metropolitan Police Service's Handling of Non-recent Sexual Offence Investigations against Persons of Public Prominence (Online redacted report). Available on the Metropolitan Police website at:

http://news.met.police.uk/documents/report-independent-review-of-metropolitan-policeservices-handling-of-non-recent-sexual-offence-investigations-61510 (accessed 6 February 2017).

HM Inspectorate of Constabulary (2013) Mistakes Were Made. Her Majesty's Inspector of Constabulary's Review into Allegations and Intelligence Material Concerning Jimmy Savile between 1964 and 2012. Available at:

https://www.justiceinspectorates.gov.uk/hmic/publications/mistakes-were-made/ (accessed 6 February 2017).

HM Inspectorate of Constabulary (2014) Crime Recording: Making the Victim Count. Available at: https://www.justiceinspectorates.gov.uk/hmic/wp-content/uploads/crimerecording-making-the-victim-count.pdf (accessed 6 February 2017).

Home Office (2016) Counting Rules for Recorded Crime (updated 2016). Available at: https://www.gov.uk/government/uploads/system/uploads/attachment_data/file/566188/countgeneral-nov-2016.pdf (accessed 6 February 2017). 
House of Commons Home Affairs Committee (2002) The Conduct of Investigations into Past Cases of Abuse in Children's Homes: Fourth Report of Session 2001-02, HC 836-1, London: The Stationery Office.

Hoyle, C., Speechley, N.-E. and Burnett, R. (2016) The Impact of Being Wrongly Accused of Abuse in Occupations of Trust: Victims' Voices, Oxford: Centre for Criminology, University of Oxford. Available at:

https://www.law.ox.ac.uk/sites/files/oxlaw/the impact_of being_wrongly accused_of abuse hoyle_speechley_burnett_final_26_may.pdf (accessed 6 February 2017).

Jamieson, R. and Grounds, A. (2005) 'Release and adjustment: perspectives from studies of wrongly convicted and politically motivated prisoners', in: A. Liebling and S. Maruna (Eds.), The Effects of Imprisonment, Cullompton: Willan.

Jay, A. (2014) Independent Inquiry into Child Sexual Exploitation in Rotherham: 1997-2013, Rotherham: Rotherham Metropolitan Borough Council.

Judicial College (2016) The Crown Court Compendium Part I: Jury and Trial Management and Summing Up, London: Judicial College.

Leahy, S. (2014) 'The corroboration warning in sexual offence trials: final vestige of the historic suspicion of sexual offence complainants or a necessary protection for defendants?', International Journal of Evidence \& Proof, $18(1), 41-64$.

Levenson. J.S., D'Amora, D.A. and Hern, A.L. (2007) 'Megan's law and its impact on community re-entry for sex offenders', Behavioural Sciences and the Law, 25(4), 587-602.

Levitt, A. (2013) Charging Perverting the Course of Justice and Wasting Police Time in Cases Involving Allegedly False Rape and Domestic Violence Allegations, London: Crown Prosecution Service.

Macur, J.W. (2016) The Report of the Macur Review: An Independent Review of the Tribunal of Inquiry into the Abuse of Children in Care in the Former County Council Areas of Gwynedd and Clwyd in North Wales since 1974, HC 701, London: HMSO.

Marshall, A. (2016) 'Recording and investigating crime' (letter from the chief executive of the College of Policing to all chief constables, police and crime commissioners and heads of public protection units, 18 March).

Metropolitan Police Service (2015) Historic Child Abuse Investigations and Operation Midland, 21 September. Available at: http://news.met.police.uk/news/historic-child-abuseinvestigations-and-operation-midland-130034 (accessed 6 February 2017).

Ministry of Justice (2015) Code of Practice for Victims, London: HMSO.

Office for National Statistics (2016) Crime in England and Wales: Year Ending December 2015. Available at:

http://www.ons.gov.uk/peoplepopulationandcommunity/crimeandjustice/bulletins /crimeinenglandandwales/yearendingdecember2015 (accessed 6 February 2017). 
Phillips, J., Gelsthorpe, L. and Padfield, N. (2016) Non-natural Deaths Following Prison and Police Custody (Equality and Human Rights Commission Research Report 106). Available at: https://www.equalityhumanrights.com/sites/default/files/research-report-106-non-naturaldeaths-following-prison-and-police-custody.pdf (accessed 6 February 2017).

Quirk, H. (2007) 'Identifying miscarriages of justice: why innocence in the UK is not the answer', Modern Law Review, 70(5), 759-77.

Rose, D. (2016) 'To catch a sex offender: police, trawls and personal injury solicitors', in: R. Burnett (Ed.), Wrongful Allegations of Sexual and Child Abuse, Oxford: Oxford University Press.

Sawyer, P. (2012) 'BBC's Newsnight airs claims of child abuse against "leading Tory politician”, Telegraph, 3 November.

Starmer, K. (2013) The Criminal Justice Response to Child Sexual Abuse: Time for a National Consensus. Available at: http://www.cps.gov.uk/news/articles/the_criminal_justice response_to_child_sexual_abuse_time_for_a national_consensus/index.html (accessed 6 February 2017).

Thomas, T. (2008) 'The sex offender "register": a case study in function creep', $\underline{\text { Howard }}$ Journal, 47, 227-37.

Waterhouse, R. (2000) Lost in Care, London: The Stationery Office.

Webster, R. (1998) The Great Children's Home Panic, Oxford: Orwell Press.

Webster, R. (2002) Similar Fact Evidence: The Origins and Erosion of the Modern Similar Fact Principle. Available at: http://www.richardwebster.net/similarfactevidence.html (accessed 6 February 2017).

Webster, R. (2005) The Secret of Bryn Estyn: The Making of a Modern Witch Hunt, Oxford: Orwell Press.

Westervelt, S. and Cook, K. (2010) 'Framing innocents: the wrongly convicted as victims of state harm', Crime, Law and Social Change, 53, 259-75.

Wildeman, J., Costelloe, M. and Schehr, R. (2011) 'Experiencing wrongful and unlawful conviction', Journal of Offender Rehabilitation, 50(7), 411-32.

Date submitted: December 2016

Date accepted: February 2017 
TABLE 1

The Enduring Impact of False Allegations

\begin{tabular}{|c|c|c|c|}
\hline $\begin{array}{l}\text { Impact of false } \\
\text { allegations }\end{array}$ & $\begin{array}{l}\text { Participants } \\
\text { affected } \\
(\mathbf{n}=\mathbf{3 0})\end{array}$ & $\begin{array}{l}\text { Impact of false } \\
\text { allegations }\end{array}$ & $\begin{array}{l}\text { Participants } \\
\text { affected } \\
(\mathbf{n}=\mathbf{3 0})\end{array}$ \\
\hline \multicolumn{2}{|c|}{ Effects on self-concept and reputation } & \multicolumn{2}{|c|}{ Effects on psychological and physical health } \\
\hline Stigma/damaged reputation & 29 & Depression & 23 \\
\hline Permanent personality changes & 19 & Anxiety or panic attacks & 23 \\
\hline Paranoia and anxiety & 18 & $\begin{array}{l}\text { Symptoms of post-traumatic stress } \\
\text { disorder (PTSD) }\end{array}$ & 17 \\
\hline Hyper-vigilance or antagonism & 15 & Disrupted sleep & 12 \\
\hline Self-blame for false accusation & 10 & Other physical symptoms & 14 \\
\hline \multicolumn{2}{|c|}{ Effect on social or family life } & \multicolumn{2}{|c|}{ Effects on beliefs and outlook } \\
\hline Fractured social network & 27 & Lost faith in criminal justice system & 28 \\
\hline Social withdrawal & 26 & Loss of trust in the police & 20 \\
\hline Strain on intimate relationship & 17 & Concerns about lack of due process & 24 \\
\hline Disruption of children's lives & 9 & Anger at employers & 23 \\
\hline $\begin{array}{l}\text { Strain on relationships with } \\
\text { children/grandchildren }\end{array}$ & 8 & Alienation and loss of confidence & 16 \\
\hline
\end{tabular}

